\title{
Responses of Kyllinga peruviana Lam. to Sea Water Spray
}

\author{
Otitoloju Kekere ${ }^{1}$ \\ ${ }^{1}$ Department of Plant Science and Biotechnology, Adekunle Ajasin University, Akungba Akoko, Ondo State, \\ Nigeria \\ Correspondence: Otitoloju Kekere, Department of Plant Science and Biotechnology, Adekunle Ajasin University, \\ Akungba Akoko, Ondo State, Nigeria. Tel: 234-806-764-6215. E-mail: kekereekunnoi@yahoo.com
}

Received: November 18, $2013 \quad$ Accepted: March 20, $2014 \quad$ Online Published: March 31, 2014
$\begin{aligned} & \text { doi:10.5539/jps.v3n2p30 } \\ & \text { URL: http://dx.doi.org/10.5539/jps.v3n2p30 }\end{aligned}$

\begin{abstract}
Response of Kyllinga peruviana Lam. to salt spray was studied to have an insight into the ecophysiological adaptations underlying the responses. Plants were exposed to foliar salt spray at: two sprays per week (2SS), four sprays per week (4SS) or six sprays per week (6SS), while those sprayed with de-ionized water served as control (CSS). Salt spray did not affect plant survival but had negative effect on growth. The growth parameters decreased except stem girth, which increased significantly in plants sprayed with seawater. Fresh and dry mass of plant parts were significantly lower under seawater treatment than in control. Total biomass, the relative growth rate and leaf total chlorophyll decreased while the root: shoot ratio increased under seawater application. Air-borne salt reduced plant xylem water potential but increased stem succulence for ion dilution. Salt spray accumulated $\mathrm{Na}+$ and $\mathrm{Cl}-$ in the aerial parts, resulting in an increased total nutrient and percentage ash content, which culminated in ion toxicity. Salt spray reduced uptake of some essential nutrients but increased $\mathrm{N}$ in the aerial parts of seawater-treated plants showing the presence of salt-related nitrogen compounds for osmotic adjustment. Significantly higher values were obtained for Na: K in plants exposed to salt spray than in the control. It led to reduction in stomata density and number of stomata per leaf by as much as $42.86 \%$ and $80.42 \%$ respectively at 6SS. Air-borne salt caused necrotic damage on the leaf with increasing application level. Generally, salt spray had no effect on the root growth. Kyllinga peruviana tolerates sea water spray by the development of some adaptations to withstand salt-related stress associated with the strandline environment.
\end{abstract}

Keywords: Cyperaceae, salt spray, beach, nutrient content, necrosis, stomata.

\section{Introduction}

Along the seashore, strandlines are areas where litter, debris and many discarded items are left behind by the previous receding tide above the high water mark (Rozema et al., 1982). Despite the worldwide distribution of strandlines, the fragility of the systems in general, their ecological, social and economic values and the potential for discovering causal limitations of plant distributions (Lee \& Ignaciuk, 1985), the vegetation of strandlines has received little attention particularly in Africa. Much of the studies on salinity tolerance have focused on saline soil or saline irrigation (Alshammary et al., 2004; Hunter \& Wu, 2005; Marcum et al., 2005) but very little attention has been given to research on plant exposure to salt spray under non-saline irrigation conditions. Unlike the salt marsh, where plant species are exposed to tidal inundation and thus to high salinity (Flowers \& Colmer. 2008), the strandline is out of reach of mean high tide and only rarely flooded with seawater (Rozema et al., 1985). Thus, salt exposure at the strandline is mainly composed of salt sprays (Rozema et al., 1985; Griffiths et al., 2006; Griffiths, 2006; De Vos et al., 2010). Studies on salinity tolerance have been conducted on the dominant strandline plant species in many parts of the world, which have offered some explanations of species abilities to grow on the strandlines (Barbour et al., 1985; Flowers \& Colmer, 2008). Consequently, morphological, growth, anatomical and physiological adaptations are likely to have been emphasized by selection and hence may be more easily recognized and quantified.

It is well documented that plants are often more sensitive to saline spray than to salt applied at the root zone (Grattan et al., 1981; Elhaak et al., 1997). It suppresses plant growth, disrupts water balance, membranes and enzyme systems (Rozema et al., 1985), inhibits nutrient uptake (Scheiber et al., 2008) and causes necrotic damage (Griffiths \& Orians, 2003; Griffiths et al., 2006). Air-borne salt led to a reduction in shoot and root growth in Triplasis purpurea (Cheplick \& Demetri, 1999), Leymus mollis (Gagne \& Houle, 2002), Myrica pensylvanica (Griffiths \& Orians, 2003), Crambe maritima (De Vos et al., 2010). Diodia maritima (Kekere \& 
Bamidele, 2012) and Commelina erecta subsp maritima (Kekere, 2013). Accumulation of chloride and sodium ions usually leads to ion toxicity and inhibition of nutrient uptake that may have negative effect on normal growth and photosynthetic activities (De Vos et al., 2010). However, some adaptive mechanisms to salt stress have been reported on coastal plants. For example, Crambe maritima minimize water loss through a reduction in leaf surface area available for transpiration. They also stated that salt spray increases water content in some plants, which is an adaptation for ion dilution (Rozema et al., 1985; De Vos et al., 2010). Also, salt spray disrupts water balance in plants, and only the tolerant species can adjust osmotically through reduced xylem water potential (Griffiths \& Orians, 2003; Griffiths, 2006). Thus, plant species growing in the strandline have adapted to salt spray in various ways (Rozema et al., 1985).

Kyllinga peruviana Lam. is sedge, belonging to the Cyperaceae family. It is rhizomatous with a distinctive spherical, white inflorescence that is densely crowed with very small greenish yellow flowers. The flowers are in spikes or spikelets and the perianth is either reduced or represents only a set of bristles or scales. It often has leafless stems and the leaves are sword shaped, narrow and flat. It propagates itself mainly by the rapid growth of its spreading rhizome. It is present throughout the West Africa coast (Hutchinson et al., 1968). The chief importance of this sedge lies in it forming a major natural constituent of wet land vegetation, where their density tangled rhizomes contribute to erosion control, shoreline stabilization and water purification (Hutchinson et al., 1968). Since it grows naturally close to the sea, I hypothesized that it has some adaptations for survival under air-borne salinity stress. A greenhouse experiment was therefore undertaken to determine the effect of different levels of salt spray on the growth of Kyllinga peruviana, to have an insight into the ecophysiological adaptations underlying the responses.

\section{Materials and Methods}

\subsection{Salt Spray Treatments}

Young rhizomes of Kyllinga peruviana collected from Lekki Beach in Lagos, Southern Nigeria were used to raise uniform plants in $20 \times 26 \mathrm{~cm}$ perforated plastic pots filled with $2: 1$ mixture $(\mathrm{v} / \mathrm{v})$ of river sand to topsoil (Cheplick \& Demetri, 1999; Khan et al., 2000). The soil had 5.48 pH, 20.42 ppm N, 3.56 ppm P, 3.56 (meg/100g) $\mathrm{K}, 2.32(\mathrm{meg} / 100 \mathrm{~g}) \mathrm{Ca}, 2.60(\mathrm{meg} / 100 \mathrm{~g}) \mathrm{Mg}, 8.2(\mathrm{meg} / 100 \mathrm{~g}) \mathrm{CEC}, 3.67 \% \mathrm{C}, 80.68 \%$ sand, $12.06 \%$ silt and $8.36 \%$ clay (Kekere \& Bamidele, 2012). It is typical of a beach soil which is sandy and low in nutrient content, and because the soil is porous, leaching rate is high and salt does not accumulate in the root zone (Griffiths \& Orians, 2003). The potted plants were placed on the greenhouse bench of Plant Science and Biotechnology Department, Adekunle Ajasin University, Akungba Akoko, Ondo State, Nigeria (Lat. $7^{0} \mathrm{~N} 28^{1}$, Long. $544^{1}$ E). Plants were randomly assigned to control and salt sprays. For salt spray treatments, air-borne seawater collected off the shore at Lekki Beach in Southern Nigeria on a single day in late July 2012 was used. The seawater was collected by the conventional method of arranging salt spray collectors parallel to the coastline at about $10 \mathrm{~m}$ from mean seawater level (mean tide line). Each salt spray collector was made up of polypropylene filter gauze wrapped over a $30 \mathrm{~cm}$ long plastic tube placed vertically in a beaker. The collectors were fixed on the ground with about $20 \mathrm{~cm}$ of the upper part exposed. The beaker was to collect precipitation and prevent loss of trapped water (Griffiths \& Orians, 2003; Doomen et al., 2006; De Vos et al., 2010; Conolly et al., 2010). The seawater was stored in a 5-L plastic jug and kept in a refrigerator at $4{ }^{\circ} \mathrm{C}$ and used for the duration of the experiment. It had salinity of $31 \mathrm{ppt}$, with sodium and chloride accounting for approximately $86 \%$ of the ions present. Spray treatments began on 30 July 2012 and lasted for 12 weeks. Plants were sprayed twice/week (on Mondays and Thursdays) with seawater at: 2 sprays/week (2SS) - 1 spray on each of the two days), 4 sprays/week (4SS) - 2 sprays on each of the two days or 6 sprays/week (6SS) - 3 sprays on each of the two days. The control treatment, in which plants were sprayed with de-ionized water 3 times on each of the two days, was designed to account for any mechanical or physical effects of the misting process. Plants were sprayed at an interval of 4 hours beginning from 08:00 am by removing plants from the watering system, taking them outside, and spraying individual plant to run-off with all the aerial parts equally exposed. Spraying was carried out using a plant mist bottle held about $20 \mathrm{~cm}$ from the shoot. The salt loads at each level of spray were estimated following the commonly used method described by (Cheplick \& Demetri, 1999). Five plants not used in the experiment but grown with the experimental plants were each immersed in $150 \mathrm{ml}$ of de-ionized water and the conductivity determined. The same shoot was sprayed once with seawater, immersed into $150 \mathrm{ml}$ of de-ionized water, and the conductivity increase was recorded. The conductivity increase was also recorded after the same shoot was sprayed twice and thrice respectively following immersion in $150 \mathrm{ml}$ of de-ionized water. This was repeated for all the 5 plants. Salt deposition was estimated per square decimeter of leaf area surface for each of the three seawater treatments at each application. The accumulated salt onto shoot for 1 spray, 2 sprays and 3 sprays equaled on average 4, 8 and $12 \mathrm{mg} \mathrm{NaCl} \mathrm{dm}^{-2}$ leaf area day ${ }^{-1}$, which fall within the levels found in the natural 
habitat of strandline plants (Barbour et al., 1985; Griffiths, 2006). Before each salt spray treatment, plastic discs were placed over the soil surface and around the base of each plant to prevent salt deposition on the soil. Also, plants were watered from the top of the soil surface at the base of the plants once per week to flush out any salts that might have been deposited onto the soil during misting, which did not remove the salts deposited onto the shoots. This was to ensure that the relative level of airborne salt deposited onto the shoots would be the primary cause of any observed effect rather than soil salinity or combined effect of both (Rozema et al., 1982; Cheplick \& Demetri, 1999; Griffiths, 2006). Salt spray was allowed to accumulate throughout the experiment, which is realistic in the field because in years with infrequent rain, salt spray is not washed off during the summer growing season (Cheplick \& Demetri, 1999; Cheplick \& White, 2002).

\subsection{Growth Measurement}

Plant survival was monitored while plant height, leaf area and stem girth were measured with meter rule, leaf area meter (LI-COR 300 model) and digital vernier caliper (model 0-200 mm) respectively. The leaves on individual plants and number of tillers were counted. Plants were destructively harvested and partitioned into leaves, stems and roots after 12 weeks of treatment. The major roots were counted and their length measured.

Fresh plant parts were weighed separately and their dry mass measured after oven-drying to constant weight at $70{ }^{\circ} \mathrm{C}$. Root: Shoot ratio (root mass/shoot mass) and the relative growth rate-RGR- (ln mass2-ln mass1)/ time were estimated.

\subsection{Determination of Water Status}

Two aspects of water status (moisture content and xylem water potential) were determined. Moisture content was calculated with the commonly used formula: [(fresh mass- dry mass)/dry mass] $\times 100$ while plant xylem water potential was measured with a plant moisture-stress instrument (PMS Instrument Co., Oregon, USA) on six randomly selected stems from each treatment. Pre-dawn xylem water potential was measured between 06.00 and 07.00 am while mid-day xylem water potential was measured between 12:00 noon and 1:00 pm.

\subsection{Leaf Chlorophyll and Mineral Content Determination}

Leaf total chlorophyll was extracted with $80 \%$ acetone following the method of Arnon (1945) and calculated with the formula: $\left(20.2 \times \mathrm{D}_{645}+8.02 \times \mathrm{D}_{663}\right) \times(50 / 1000) \times(100 / 5) \times 1 / 2$, where $\mathrm{D}=$ absorbance. Soil physicochemical parameters and plant nutrient content were assayed following the standard methods of the Association of Official Analytical Chemists (AOAC, 1985) in the Central Laboratory of The National Institute for Oil Palm Research (NIFOR), Nigeria.

\subsection{Measurement of Stomata and Necrosis}

Stomata number and necrotic damage were estimated on the leaves used for the determination of moisture content following the method described by Hwang and Chen (1995). The stomata number per leaf was estimated as the product of stomata density and leaf area. The area of leaf tissue with necrotic damage was measured using a dot grid and expressed as the percentage of total leaf area showing necrosis (Griffiths \& Orians, 2003; Griffiths et al., 2006).

\subsection{Statistical Analysis}

The experiment was completely randomized with six single-plant replicates. Data were subjected to single factor ANOVA and means were separated with Tukey Honest Significant Difference (HSD) test using SPSS version 17.0 software (SPSS Inc., Chicago, IL, USA) at $\mathrm{P}<0.05$.

\section{Results}

Salt spray did not lead to plant mortality since the control and salt-treated plants had $100 \%$ survival, but plant growth was negatively affected (Table 1). Plant height, leaf area, number of leaves and tillers/plant decreased significantly in plants sprayed with seawater when compared with those exposed to salt spray. Seawater treatments significantly increased stem girth but had no effect on the number and length of roots. 
Table 1. Percentage survival and some growth parameters of Kyllinga peruviana after 12 weeks of exposure to different levels of salt spray

\begin{tabular}{|c|c|c|c|c|c|c|c|c|}
\hline $\begin{array}{l}\text { Level } \\
\text { of salt } \\
\text { spray }\end{array}$ & $\begin{array}{l}\text { Survival } \\
(\%)\end{array}$ & $\begin{array}{l}\text { Stem } \\
\text { girth } \\
(\mathrm{cm})\end{array}$ & $\begin{array}{l}\text { Leaf } \\
\text { area } \\
\left(\mathrm{cm}^{2}\right)\end{array}$ & $\begin{array}{l}\text { Number } \\
\text { of leaves } \\
\text { plant }^{-1}\end{array}$ & $\begin{array}{l}\text { Number } \\
\text { of tillers } \\
\text { plant }^{-1}\end{array}$ & $\begin{array}{l}\text { Plant } \\
\text { height } \\
(\mathrm{cm})\end{array}$ & $\begin{array}{l}\text { Number } \\
\text { of } \\
\text { Roots } \\
\text { plant }^{-1}\end{array}$ & $\begin{array}{l}\text { Root } \\
\text { length } \\
\text { (cm) }\end{array}$ \\
\hline CSS & 100.00 & $0.27^{\mathrm{a}}$ & $15.15^{\mathrm{a}}$ & $14.65^{\mathrm{a}}$ & $18.24^{\mathrm{a}}$ & $43.64^{\mathrm{a}}$ & $77.00^{\mathrm{ab}}$ & $36.50^{\mathrm{a}}$ \\
\hline 2SS & 100.00 & $0.33^{\mathrm{b}}$ & $8.85^{\mathrm{b}}$ & $7.34^{\mathrm{b}}$ & $14.21^{b}$ & $38.86^{\mathrm{b}}$ & $80.00^{\mathrm{ab}}$ & $39.00^{\mathrm{a}}$ \\
\hline $4 \mathrm{SS}$ & 100.00 & $0.32^{\mathrm{b}}$ & $7.84^{\mathrm{b}}$ & $6.90^{\mathrm{b}}$ & $14.02^{b}$ & $36.73^{b}$ & $88.33^{\mathrm{a}}$ & $42.00^{\mathrm{a}}$ \\
\hline 6SS & 100.00 & $0.34^{\mathrm{b}}$ & $5.19^{\mathrm{b}}$ & $7.34^{\mathrm{b}}$ & $14.65^{b}$ & $34.24^{\mathrm{b}}$ & $87.61^{\mathrm{a}}$ & $39.17^{\mathrm{a}}$ \\
\hline
\end{tabular}

Each value is a mean of 6 replicates. For each parameter, means with the same letter(s) [in superscript] in the same column are not significantly different at $\mathrm{P}<0.05$ (Tukey HSD). CSS $=$ deionized water sprays (control), $2 \mathrm{SS}=$ two salt sprays per week, $4 \mathrm{SS}=$ four salt sprays per week, $6 \mathrm{SS}=$ six salt sprays per week.

Fresh and dry mass values of the leaf, stem and shoot were significantly lower in plants sprayed with seawater than in those sprayed with de-ionized water, but the values for the root did not differ significantly. In addition, total biomass, the relative growth rate and leaf total chlorophyll (LTC) decreased while the root: shoot ratio increased as a result of seawater application (Table 2). Air-borne salinity increased stem succulence with increasing level of application (Table 3), by up to $14.75 \%$ increase over the control at the highest application level (6SS). Moisture content of other plant parts was however not affected by salt spray. Plant xylem water potential was lower under air-borne salinity treatment than did control plants, and they significantly differed from each other as the application level increased (Table 3). The mid-day values were slightly lower that those of the predawn.

Table 2. Fresh and dry mass, root: shoot ratio, relative growth rate (RGR) and leaf total chlorophyll (LTC) of Kyllinga peruviana after 12 weeks of exposure to different levels of salt spray

\begin{tabular}{|c|c|c|c|c|c|c|c|c|c|c|c|c|}
\hline $\begin{array}{l}\text { Salt } \\
\text { spray }\end{array}$ & $\begin{array}{l}\text { Leaf } \\
\text { fresh } \\
\text { mass } \\
\text { (g) }\end{array}$ & $\begin{array}{l}\text { Stem } \\
\text { fresh } \\
\text { mass } \\
(g)\end{array}$ & $\begin{array}{l}\text { Root } \\
\text { fresh } \\
\text { mass } \\
\text { (g) }\end{array}$ & $\begin{array}{l}\text { Shoot } \\
\text { fresh } \\
\text { mass } \\
\text { (g) }\end{array}$ & $\begin{array}{l}\text { Leaf } \\
\text { dry } \\
\text { mass } \\
\text { (g) }\end{array}$ & $\begin{array}{l}\text { Stem } \\
\text { dry } \\
\text { mass } \\
(\mathrm{g})\end{array}$ & $\begin{array}{l}\text { Root } \\
\text { dry } \\
\text { mass } \\
\text { (g) }\end{array}$ & $\begin{array}{l}\text { Shoot } \\
\text { dry } \\
\text { mass } \\
\text { (g) }\end{array}$ & $\begin{array}{l}\text { Total } \\
\text { biomass } \\
\text { (g) }\end{array}$ & $\begin{array}{l}\text { Root: } \\
\text { shoot }\end{array}$ & $\begin{array}{l}\text { RGR } \\
\left(\mathrm{gg}^{-1} \mathbf{d}^{-1}\right)\end{array}$ & $\begin{array}{l}\text { LTC } \\
\text { (mgg }^{-1} \\
\text { Fresh } \\
\text { leaves) }\end{array}$ \\
\hline CSS & & 1.12 & $21.67^{\mathrm{a}}$ & . & ${ }^{2}$ & $18.67^{\mathrm{a}}$ & $38^{\mathrm{a}}$ & $25.48^{\mathrm{a}}$ & 37. & & & $2.17^{\mathrm{a}}$ \\
\hline $2 \mathrm{SS}$ & $4.37^{\mathrm{b}}$ & $30.95^{\mathrm{b}}$ & $18.72^{\mathrm{a}}$ & $35.47^{\mathrm{b}}$ & $3.39^{\mathrm{b}}$ & $14.5^{\mathrm{a}}$ & $11.78^{\mathrm{a}}$ & $18.10^{\mathrm{b}}$ & $28.75^{\mathrm{b}}$ & $2^{b}$ & $0.0953^{\mathrm{b}}$ & $1.72^{\mathrm{b}}$ \\
\hline 4SS & $4.02^{\mathrm{b}}$ & $27.73^{b}$ & $19.27^{\mathrm{a}}$ & $31.79^{b}$ & $3.24^{\mathrm{b}}$ & $12.6^{\mathrm{a}}$ & $10.96^{\mathrm{a}}$ & $15.89^{b}$ & $26.69^{b}$ & $0.34^{\mathrm{b}}$ & $0.0925^{\mathrm{b}}$ & $1.68^{\mathrm{b}}$ \\
\hline 6SS & $3.04^{\mathrm{b}}$ & $24.48^{\mathrm{b}}$ & $18.43^{\mathrm{a}}$ & $27.65^{\mathrm{bc}}$ & $2.47^{\mathrm{b}}$ & $10.67^{\mathrm{b}}$ & $11.30^{\mathrm{a}}$ & $13.27^{\mathrm{b}}$ & $23.54^{\mathrm{b}}$ & $0.37^{\mathrm{b}}$ & $0.0954^{\mathrm{b}}$ & $1.24^{\mathrm{b}}$ \\
\hline
\end{tabular}

Each value is a mean of 6 replicates. For each parameter, means with the same letter(s) [in superscript] in the same column are not significantly different at $\mathrm{P}<0.05$ (Tukey HSD). RGR = relative growth rate, $\mathrm{LTC}=$ leaf total chlorophyll, CSS = deionized water sprays (control), $2 \mathrm{SS}=$ two salt sprays per week, $4 \mathrm{SS}=$ four salt sprays per week, $6 \mathrm{SS}=$ six salt sprays per week.

Except $\mathrm{Ca}^{2+}$ that showed a slight increase, other nutrients including $\mathrm{Mg}^{2+}, \mathrm{K}^{+}$and $\mathrm{Fe}^{2+}$ had less values in the aerial parts of salt-treated plants than did control, although did not differ significantly except $\mathrm{Fe}^{2+}$ in the leaf at 6SS (Table 4). Plants exposed to air-borne salinity had higher $\mathrm{N}$ content in the aerial parts with values that differed significantly from the control. Salt spray also resulted in $\mathrm{Na}^{+}$and $\mathrm{Cl}^{-}$accumulation in the aerial parts of plants with increasing level of seawater applications. This accumulation led to a significantly higher total nutrient and percentage ash content in leaf and stem (Table 4). In addition, significantly higher values were obtained for Na: $\mathrm{K}$ in plants exposed to salt spray than in the control. In the root however, there was generally no effect of air-borne salt on the nutrient content except for a slight decrease in $\mathrm{Mg}^{2+}$ and an increase in $\mathrm{Na}^{+}$and $\mathrm{Cl}^{-}$that did not differ from the control. Salt spray led to a more scattered stomata on the leaf surface (Plate A) bringing about a reduced stomata density and number of stomata per leaf by as much as $42.86 \%$ and $80.42 \%$ 
respectively at 6SS- the highest level of application (Table 5). Also, air-borne salt increased the necrotic leaf area with increasing application level, which differed significantly from those sprayed with de-ionized water (Table $5)$.

Table 3. Water status of Kyllinga peruviana after 12 weeks of exposure to different levels of salt spray

\begin{tabular}{lllllll}
\hline $\begin{array}{l}\text { Salt } \\
\text { spray } \\
\text { Level }\end{array}$ & $\begin{array}{l}\text { Leaf } \\
\text { moisture } \\
\text { content } \\
\mathbf{( \% )}\end{array}$ & $\begin{array}{l}\text { Stem } \\
\text { moisture } \\
\text { content } \\
\mathbf{( \% )}\end{array}$ & $\begin{array}{l}\text { Root } \\
\text { moisture } \\
\text { content } \\
(\%)\end{array}$ & $\begin{array}{l}\text { Shoot } \\
\text { moisture } \\
\text { content } \\
(\%)\end{array}$ & $\begin{array}{l}\text { Pre-dawn } \\
\text { water } \\
\text { potential } \\
(-M P a)\end{array}$ & $\begin{array}{l}\text { Mid-day } \\
\text { water } \\
\text { potential } \\
(-M P a)\end{array}$ \\
\hline $\mathbf{C S S}$ & $23.10^{\mathrm{a}}$ & $49.16^{\mathrm{a}}$ & $42.96^{\mathrm{a}}$ & $44.37^{\mathrm{a}}$ & $1.00^{\mathrm{d}}$ & $1.03^{\mathrm{d}}$ \\
$\mathbf{2 S S}$ & $21.01^{\mathrm{a}}$ & $53.15^{\mathrm{b}}$ & $42.31^{\mathrm{a}}$ & $49.07^{\mathrm{b}}$ & $2.50^{\mathrm{c}}$ & $3.00^{\mathrm{c}}$ \\
$\mathbf{4 S S}$ & $19.00^{\mathrm{a}}$ & $54.56^{\mathrm{b}}$ & $43.95^{\mathrm{a}}$ & $49.95^{\mathrm{b}}$ & $4.50^{\mathrm{b}}$ & $4.80^{\mathrm{b}}$ \\
$\mathbf{6 S S}$ & $18.10^{\mathrm{a}}$ & $56.41^{\mathrm{b}}$ & $44.22^{\mathrm{a}}$ & $52.06^{\mathrm{b}}$ & $5.62^{\mathrm{a}}$ & $6.00^{\mathrm{a}}$
\end{tabular}

Each value is a mean of 6 replicates. For each parameter, means with the same letter(s) [in superscript] in the same column are not significantly different at $\mathrm{P}<0.05$ (Tukey HSD). CSS $=$ deionized water sprays (control), $2 \mathrm{SS}=$ two salt sprays per week, $4 \mathrm{SS}=$ four salt sprays per week, $6 \mathrm{SS}=$ six salt sprays per week.

Table 4. Effect of salt spray on nutrient content ( $\mathrm{mmolg}^{-1}$ dry weight) and ash content (\% dry weight) of the leaf, stem and root of Kyllinga peruviana after 12 weeks of exposure to salt spray

\begin{tabular}{|c|c|c|c|c|c|c|c|c|c|c|c|}
\hline $\begin{array}{c}\text { Plant } \\
\text { Part }\end{array}$ & $\begin{array}{c}\text { Salt } \\
\text { Spray } \\
\text { level }\end{array}$ & $\mathrm{Ca}^{2+}$ & $\mathbf{M g}^{2+}$ & $\mathrm{Na}^{+}$ & $\mathbf{K}^{+}$ & $\mathrm{Fe}^{2+}$ & $\mathrm{Cl}^{-}$ & $\mathbf{N}$ & Total & Na: K & Ash \\
\hline \multirow{5}{*}{ Leaf } & CSS & $3.12^{\mathrm{a}}$ & $2.72^{\mathrm{a}}$ & $0.72^{\mathrm{d}}$ & $3.92^{\mathrm{a}}$ & $0.33^{\mathrm{a}}$ & $0.98^{\mathrm{d}}$ & $1.56^{\mathrm{a}}$ & $13.35^{\mathrm{d}}$ & $0.18^{\mathrm{d}}$ & $5.91^{\mathrm{a}}$ \\
\hline & 2SS & $4.16^{\mathrm{a}}$ & $2.52^{\mathrm{a}}$ & $10.96^{b c}$ & $3.88^{\mathrm{a}}$ & $0.25^{\mathrm{ab}}$ & $3.96^{\mathrm{bc}}$ & $3.38^{\mathrm{b}}$ & $29.11^{b c}$ & $2.82^{b c}$ & $9.24^{\mathrm{b}}$ \\
\hline & $4 S S$ & $3.32^{\mathrm{a}}$ & $2.48^{\mathrm{a}}$ & $16.84^{\mathrm{b}}$ & $3.40^{\mathrm{a}}$ & $0.22^{\mathrm{ab}}$ & $6.66^{\mathrm{b}}$ & $3.46^{\mathrm{b}}$ & $36.38^{\mathrm{b}}$ & $4.9^{\mathrm{ab}}$ & $13.15^{\mathrm{c}}$ \\
\hline & & & & & & & & & & & \\
\hline & $6 S S$ & $5.24^{\mathrm{a}}$ & $2.04^{\mathrm{a}}$ & $25.36^{\mathrm{a}}$ & $3.48^{\mathrm{a}}$ & $0.17^{\mathrm{b}}$ & $11.32^{\mathrm{a}}$ & $3.25^{\mathrm{b}}$ & $50.86^{\mathrm{a}}$ & $7.29^{\mathrm{a}}$ & $14.21^{\mathrm{c}}$ \\
\hline \multirow{5}{*}{ Stem } & CSS & $3.03^{\mathrm{a}}$ & $2.40^{\mathrm{a}}$ & $0.68^{\mathrm{d}}$ & $5.32^{\mathrm{a}}$ & $0.14^{\mathrm{a}}$ & $0.52^{\mathrm{d}}$ & $1.12^{\mathrm{b}}$ & $13.30^{\mathrm{c}}$ & $0.13^{\mathrm{c}}$ & $8.87^{\mathrm{a}}$ \\
\hline & $2 S S$ & $3.61^{\mathrm{a}}$ & $2.08^{\mathrm{a}}$ & $5.40^{\mathrm{c}}$ & $4.32^{\mathrm{a}}$ & $0.15^{\mathrm{a}}$ & $3.89^{\mathrm{c}}$ & $3.74^{\mathrm{a}}$ & $23.74^{\mathrm{b}}$ & $1.25^{\mathrm{ab}}$ & $12.65^{\mathrm{b}}$ \\
\hline & & & & & & & & & & & \\
\hline & $4 S S$ & $3.43^{\mathrm{a}}$ & $1.00^{\mathrm{a}}$ & $10.20^{\mathrm{b}}$ & $3.32^{\mathrm{a}}$ & $0.12^{\mathrm{a}}$ & $6.04^{\mathrm{bc}}$ & $4.09^{\mathrm{a}}$ & $28.09^{\mathrm{b}}$ & $3.07^{\mathrm{a}}$ & $17.72^{\mathrm{c}}$ \\
\hline & $6 S S$ & $4.33^{\mathrm{a}}$ & $0.60^{\mathrm{a}}$ & $16.72^{\mathrm{a}}$ & $3.60^{\mathrm{a}}$ & $0.11^{\mathrm{a}}$ & $10.30^{\mathrm{a}}$ & $4.24^{\mathrm{a}}$ & $40.81^{\mathrm{a}}$ & $4.64^{\mathrm{a}}$ & $17.81^{\mathrm{c}}$ \\
\hline \multirow{4}{*}{ Root } & CSS & $2.87^{\mathrm{a}}$ & $2.64^{\mathrm{a}}$ & $0.28^{\mathrm{a}}$ & $0.37^{\mathrm{a}}$ & $0.17^{\mathrm{a}}$ & $0.36^{\mathrm{a}}$ & $2.74^{\mathrm{a}}$ & $9.21^{\mathrm{a}}$ & $0.79^{\mathrm{a}}$ & $9.01^{\mathrm{a}}$ \\
\hline & $2 \mathrm{SS}$ & $2.89^{\mathrm{a}}$ & $1.56^{\mathrm{a}}$ & $0.30^{\mathrm{a}}$ & $0.36^{\mathrm{a}}$ & $0.18^{\mathrm{a}}$ & $0.53^{\mathrm{a}}$ & $2.82^{\mathrm{a}}$ & $8.57^{\mathrm{a}}$ & $0.83^{\mathrm{a}}$ & $9.23^{\mathrm{a}}$ \\
\hline & $4 \mathrm{SS}$ & $2.32^{\mathrm{a}}$ & $1.63^{\mathrm{a}}$ & $0.31^{\mathrm{a}}$ & $0.38^{\mathrm{a}}$ & $0.14^{\mathrm{a}}$ & $0.73^{\mathrm{ab}}$ & $2.57^{\mathrm{a}}$ & $8.13^{\mathrm{a}}$ & $0.81^{\mathrm{a}}$ & $9.10^{\mathrm{a}}$ \\
\hline & 6SS & $3.19^{\mathrm{a}}$ & $2.08^{\mathrm{a}}$ & $0.31^{\mathrm{a}}$ & $0.39^{\mathrm{a}}$ & $0.17^{\mathrm{a}}$ & $0.70^{\mathrm{ab}}$ & $2.52^{\mathrm{a}}$ & $9.40^{\mathrm{a}}$ & $0.79^{\mathrm{a}}$ & $8.98^{\mathrm{a}}$ \\
\hline
\end{tabular}

Each value is a mean of 3 replicates. For each plant part and variable, means with the same letter(s) [in superscript] in the same column are not significantly different at $\mathrm{P}<0.05$ (Tukey HSD). CSS $=$ deionized water sprays (control), $2 \mathrm{SS}=$ two salt sprays per week, $4 \mathrm{SS}=$ four salt sprays per week, $6 \mathrm{SS}=$ six salt sprays per week. 
Table 5. Some anatomical parameters measured on the leaf of Kyllinga peruviana after 12 weeks of exposure to salt spray

\begin{tabular}{llll}
\hline $\begin{array}{l}\text { Level of } \\
\text { salt spray }\end{array}$ & $\begin{array}{l}\text { Stomata } \\
\text { density } \\
\left(\mathbf{n o} / \mathbf{c m}^{2}\right)\end{array}$ & $\begin{array}{l}\text { Number of } \\
\text { stomata } \\
\text { /leaf) }\end{array}$ & $\begin{array}{l}\text { Necrotic } \\
\text { leaf area } \\
\mathbf{( \% )}\end{array}$ \\
\hline $\mathbf{C S S}$ & $89115.20^{\mathrm{a}}$ & $1350071.38^{\mathrm{a}}$ & $0.57^{\mathrm{a}}$ \\
$\mathbf{2 S S}$ & $63653.72^{\mathrm{b}}$ & $563321.29^{\mathrm{b}}$ & $11.32^{\mathrm{b}}$ \\
$\mathbf{4 S S}$ & $57288.35^{\mathrm{bc}}$ & $449123.39^{\mathrm{b}}$ & $15.26^{\mathrm{b}}$ \\
$\mathbf{6 S S}$ & $50922.98^{\mathrm{bc}}$ & $264279.54^{\mathrm{c}}$ & $14.64^{\mathrm{b}}$ \\
\hline
\end{tabular}

Each value is a mean of 6 replicates. Means with the same letter(s) [in superscript] in the same column are not significantly different at $\mathrm{P}<0.05$ (Tukey HSD). CSS $=$ deionized water sprays (control), $2 \mathrm{SS}=$ two salt sprays per week, $4 \mathrm{SS}=$ four salt sprays per week, $6 \mathrm{SS}=$ six salt sprays per week.

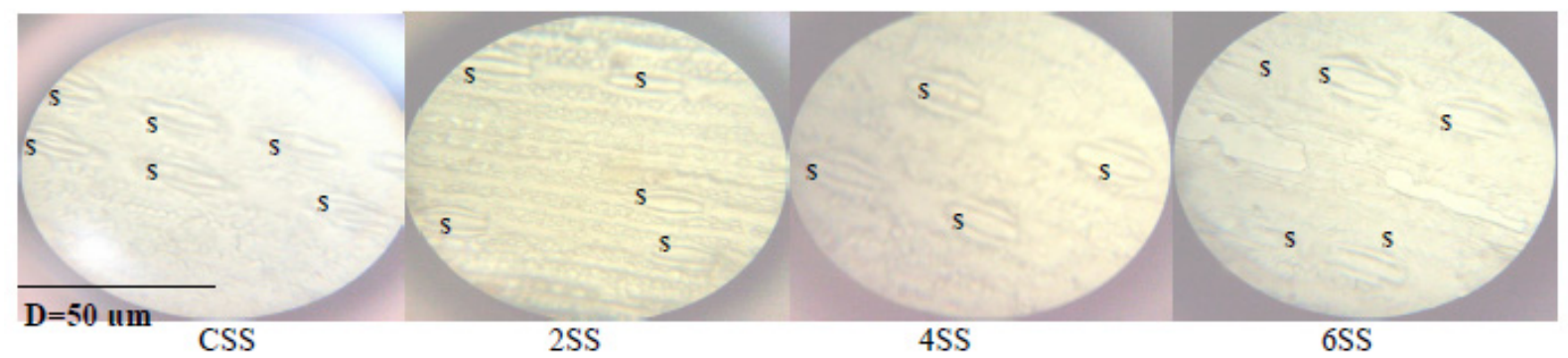

Plate A. Stomata appearance on the abaxial leaf surface of Kyllinga peruviana after 12 weeks of exposure to salt spray. $\mathrm{S}=$ stoma, $\mathrm{D}=$ diameter, $\mathrm{CSS}=$ deionized water sprays (control), $2 \mathrm{SS}=$ two salt sprays per week, $4 \mathrm{SS}=$ four salt sprays per week, $6 \mathrm{SS}=$ six salt sprays per week

\section{Discussion}

The soil used for planting was suitable for the growth of $K$. peruviana since no symptom of nutrient deficiency was observed in the control plants. Plant survival under air-borne salinity has been linked with ability to cope with salt stress (Gagne \& Houle, 2002). Salt spray tolerant plants occupy sea-side while sensitive species are eliminated and are found inland far away from the beach (Ogura \& Yura, 2007; Scheiber et al., 2008). Ogura \& Yura (2007) reported that the death of Impereta cylindrica and Miscanthus sinensis transplanted to beach was as a result of salt spray, inhibiting them from becoming established on the front dunes. They concluded that salt spray was among the non-negligible factors controlling the distribution of plants in sand dune vegetation. Air-borne salinity has been reported to cause growth reduction in many plant species, such as reduction in leaf expansion and stem elongation in Leymus mollis (Gagne \& Houle, 2002) and Myrica. pensylvanica (Griffiths \& Orians, 2003). Air-borne salt reduced tiller number in Kyllinga peruviana similar to the observations of Cheplick and Demetri (1999) that the final number of tillers in Triplasis purpurea was significantly reduced for salt-sprayed plants relative to the control. Reduction in plant height, number of branches and number of leaves was also recorded in Miscanthus sinensis and Pennisetum alopecuroides (Scheiber et al., 2008), Crambe maritima (De Vos et al., 2010) and Diodia maritima (Kekere \& Bamidele, 2012). Reduced number of leaves was due to leaf firing, browning and necrotic damage caused by $\mathrm{Na}^{+}$and $\mathrm{Cl}^{-}$deposition. The injury caused by salt spray led to early leaf senescence and defoliation, as observed in Pinu rigida seedlings (Griffiths \& Orians, 2004). Also, fewer leaves and reduced leaf size have direct effect on the leaf surface area available for light interception for photosynthetic activities, with consequential effect on growth (De Vos et al., 2010). Reduced leaf area under salt spray was similarly observed in Crambe maritima (De Vos et al., 2010), Diodia maritima (Kekere $\&$ Bamidele, 2012) and Commelina erecta subsp maritima (Kekere, 2013), which can be attributed to inhibition of leaf expansion.

However, a field of thought opined that salt spray accumulation on coastal plants is closely correlated with reduced height and an absence of trees, which could be one mechanism through which the characteristic dwarf stature of strand vegetation is maintained (Griffiths \& Orians, 2003). Reduction in leaf area brings about a 
decrease in the surface available for salt deposition and water loss through transpiration, which are strategies to cope with water stress (Morant-Manceau et al., 2004). Chlorophyll content decrease could be due to leaf damage. Application of $\mathrm{NaCl}$ to plant foliage induced fragmented cuticles, disrupted stomata, collapsed cell walls, coarsely granulated cytoplasm, disintegrated chloroplasts and nuclei, and disorganized phloem, thus reducing growth (Touchette, 2009). Also, inhibition of essential nutrients uptake must have led to chlorophyll reduction, because certain elements such as $\mathrm{Mg}^{2+}$ and $\mathrm{Fe}^{2+}$ are important for normal growth and are part of chlorophyll ultrastructure (Touchette, 2009). Similar to this study, Scaevola sericea seedlings had reduced stem mass, leaf mass, shoot mass and total biomass with increasing level of sea spray Goldstein et al. (1996). Reduction in growth parameters must have led to biomass reduction.

Induced stem succulence in seawater-treated K. peruviana is in agreement with the results of De Vos et al. (2010) on Crambe maritima. Salt-tolerant plants have been shown to increase their moisture content for ion dilution (Rozema et al., 1985). In a previous study, Griffiths \& Orians (2003) reported a significant reduction in xylem water potential in Solidago puberula, Solidago rugosa, Gaylussacia baccata, Myrica pensylvanica, Pinus rigida and Quercus ilicifolia sprayed with seawater.

Air-borne salt can cause nutrient imbalance in plants. $\mathrm{Na}^{+}$and $\mathrm{Cl}^{-}$accumulation usually results in ion toxicity. $\mathrm{Na}^{+}$toxicity for instance has been linked with disruption of nutrient uptake, development of water stress, reduction of turgor and induction of oxidative cell damage (Rozema et al., 1982). In the other hand, increase in certain elements and accumulation of $\mathrm{Na}^{+}$and $\mathrm{Cl}^{-}$by salt spray can be an adaptive mechanism to contribute to the osmotic potential, and thereby increase the protection against osmotic stress (Touchette, 2009). Ashraf and Harris (2004) results indicated that much of $\mathrm{N}$ contents under seawater salinity were probably used in synthesis of specific $\mathrm{N}$ compounds such as amino acids (e.g. proline and aspartic acids), amides (glutamine and asparagine) and the stress-related proteins for osmotic adjustment. They observed that most salt tolerant plants accumulate $\mathrm{Na}^{+}$in their shoots whereas sensitive plants do not, and a more efficient $\mathrm{K}^{+}$uptake represents plant adaptation to salinity. They also stated that Na: $\mathrm{K}$ ratio can be used as phyto-physiological parameters for screening plants for $\mathrm{NaCl}$ stress. Hence, a high $\mathrm{Na}$ : $\mathrm{K}$ ratio indicates metabolic disorders such as a reduction in protein synthesis and enzyme activities and an increase in membrane permeability. All these must have been responsible for growth reduction.

Reduction of stomata number on leaf surface as recorded in this study must have decreased the entry points to salt spray and minimized water loss through transpiration, in conformity with the study on Kandelia candel (Hwang \& Chen, 1995). The sensitivity of the studied plant to necrotic damage confirms the result on $M$. pensylvanica that necrotic laves decreased as distance from the dune crest increased (Griffiths \& Orians, 2003). Likewise, the needles of Pinus rigida seedlings were reported to show high levels of necrotic damage close to the ocean due to salt spray (Griffiths \& Orians, 2004). Griffiths and Orians (2003) observed that necrosis increased with increasing levels of salt spray in the leaves of Solidago puberula, Solidago rugosa, Gaylussacia baccata and Quercus ilicifolia. The necrotic damage must have resulted in a decrease in net photosynthesis that was expressed in reduced growth (Griffiths, 2006).

In conclusion, the study showed that Kyllinga peruviana is tolerant to air-borne salinity. It grows naturally in the strandline because it has developed some adaptations to cope with salt-related stress. Reduction in leaf size was to minimize water loss through transpiration and decreased the surface area available for salt deposition. Fewer stomata on the leaf surface could reduce the entry points for salt penetration and decreased loss of water through transpiration. $\mathrm{N}$ accumulation was an evidence of the presence of salt stress-related nitrogen compounds, which could help in for osmotic adjustment. Reduction in the xylem water potential was to adjust to water stress caused by salt spray. Increase in stem succulence was for ion dilution to minimize ion toxicity.

\section{References}

Alshammary, S. F., Qian, Y. L., \& Wallner, S. J. (2004). Growth response of four turfgrass species to salinity. Agriculture and Water Management, 66, 97-111. http://dx.doi.org/10.1016/j.agwat.2003.11.002

Arnon, D. I. (1949). Copper enzymes in isolated chloroplast and polyperoxidase in Phaseolus vulgaris. Plant Physiology, 24, 1-15. http://dx.doi.org/10.1104/pp.24.1.1

Ashraf, M., \& Harris, P. J. C. (2004). Potential indicators of salinity tolerance in plants. Plant Science, 166, 3-16. http://dx.doi.org/10.1016/j.plantsci.2003.10.024

Association of Official Analytical Chemists [AOAC]. (1985). Official methods of analysis (12th edition). pp. $55-58$.

Barbour, M., DeJong, T. M., \& Pavlik, B. M. (1985). In B. F. Chabot \& H. A. Mooney (Eds.), Marine beach and 
dune plant communities (pp. 296-322). Physiological ecology of North American plant communities, Chapman and Hall, New York, NY.

Bernstein, L., Francois, L. E., \& Clark, R. A. (1972). Salt tolerance of ornamental shrubs and ground covers. Journal of American Society of Horticultural Science, 97, 550-556.

Cheplick, G. P., \& Demetri, H. (1999). Impact of saltwater spray and sand deposition on the coastal annual Triplasis purpurea (Poaceae). American Journal of Botany, 86(5), 703-710. http://dx.doi.org/10.2307/2656580

Cheplick, G. P., \& White, T. P. (2002). Saltwater spray as an agent of natural selection: no evidence of local adaptation within a coastal population of Triplasis purpurea (Poaceae). American Journal of Botany, 89, 623-631. http://dx.doi.org/10.3732/ajb.89.4.623

Conolly, N. B., Bassuk, N. I., \& MacRae, Jr P. F. (2010). Response of five hydrangea species to foliar salt spray. Journal of Environmental Horticulture, 28(3), 125-128.

De Vos, A. C., Broekman, R., Groot, M. P., \& Rozema, J. (2010). Ecophysiological response of Crambe maritima to air-borne and soil-borne salinity. Annals of Botany, 105(6), 925-937. http://dx.doi.org/10.1093/aob/mcq072

Doomen, A., Van Bodegom, P., Meuleman, A., Assendorp, D., \& De Bruyne, R. (2006). Monitoring ecologie van het duingebied van Voorne en Goeree. Kiwa Water Research B.V., Nieuwegein. 06.060.

Elhaak, M. A., Migahid, M. M., \& Wegmann, K. (1997). Ecophysiological studies on Euphorbia paraliasunder, soil salinity and sea water spray treatments. Journal of Arid Environments, 35(3), 459-471. http://dx.doi.org/10.1006/jare.1995.0151

Flowers, T. J., \& Colmer, T. D. (2008). Salinity tolerance in halophytes. New Phytologist, 179, $945-963$. http://dx.doi.org/10.1111/j.1469-8137.2008.02531.x

Gagne, J. M., \& Houle, G. (2002). Factors responsible for Honckenya peploides (Caryophyllaceae) and Leymus mollis (Poaceae) spatial segregation on subarctic coastal dunes. American Journal of Botany, 89, 479-485. http://dx.doi.org/10.3732/ajb.89.3.479

Goldstein, G., Alpha, C. G., \& Drake, D. R. (1996). Morphological and physiological responses of Scaevola sericea (Goodeniaceae) seedlings to salt spray and substrate salinity. American Journal of Botany, 83, 86-92. http://dx.doi.org/10.2307/2445958

Grattan, S. R., Maas, E. V., \& Ogata, G. (1981). Foliar uptake and injury from saline aerosol. Journal of Environmental Quality, 10, 406-409. http://dx.doi.org/10.2134/jeq1981.103406x

Griffiths, M. E. (2006). Salt spray and edaphic factors maintain dwarf stature and community composition in coastal sandplain heathlands. Plant Ecology, 186, 69-86. http://dx.doi.org/10.1007\%2Fs11258-006-9113-8

Griffiths, M. E., \& Orians, C. M., (2003). Responses of common and successional heathland species to manipulated salt spray and water availability. American Journal of Botany, 90, 1720-1728. http://dx.doi.org/10.3732/ajb.90.12.1720

Griffiths, M. E., \& Orians, C. M. (2004). Salt spray effects on forest succession in rare coastal sandplain heathlands, evidence from field surveys and Pinus rigida transplant experiments. Journal of the Torrey Botanical Society, 131, 23-31. http://dx.doi.org/10.2307/4126925

Griffiths, M. E., Keithac, R. P., \& Orians, C. M. (2006). Direct and indirect effects of salt spray and fire on coastal heathland plant physiology and community composition. Rhodora, 108(9), 32-42. http://dx.doi.org/10.3119/05-16.1

Hunter, K. A., \& Wu, L. (2005). Morphological and physiological response of five California native grass species to moderate salt spray, Implications for landscape irrigation with reclaimed water. Journal of Plant Nutrition, 2, 247-270. http://dx.doi.org/10.1081/PLN-200047609

Hutchinson, J., Dalziel, J. M., \& Hepper, F. N. (1968). Phylogenic sequence of orders and families. In: Flora of West Tropical Africa. Published by Crown Agents for Overseas Governments and Administrations, Volume III, Part 1, Millibank, London, S. W. 1. p. 574.

Hwang, Y., \& Chen, S. (1995). Anatomical responses in Kandelia candel (L) Druce seedlings growing in the presence of different concentrations of NaCl. Bulletin of Botanical Society of Academia Sinica, 36, 181-188. 
Kekere, O. (2013). Effect of Air-Borne Salinity on the Growth and Appearance of the Tropical Perennial Strandline Plant, Commelina erecta subsp. maritima (C.V. Morton) C.V. Morton. Sustainable Agriculture Research, 3(2), 77-88.

Kekere, O., \& Bamidele, J. F. (2012). Growth response of a strandline plant, Diodia maritima Thonn from Southern Nigeria to air-borne salinity. International Journal of Academic Research, 4(1), 84-89.

Khan, M. A., Ungar, I. A., \& Showalter, A. M. (2000). Effects of salinity on growth, water relations and ion accumulation of the subtropical perennial halophyte, Atriplex griffithii var. stocksii. Annals of Botany, 85, 225-232. http://dx.doi.org/10.1006/anbo.1999.1022

Lee, J. A., \& Ignaciuk, R. (1985). The physiological ecology of strandline plants. Plant Ecology, 62(1-3), 15-19.

Marcum, K. B., Pessarakli, M., \& Kopec, D. (2005). Relative salinity tolerance of 21 turf-type desert salt grasses compared to bermudagrass. HortScience, 40, 827-829.

Morant-Manceau, A., Pradier, E., \& Tremblin, G. (2004). Osmotic adjustment, gas exchanges and chlorophyll fluorescence of a hexaploid triticale and its parental species under salt stress. Journal of Plant Physiology, 161(1), 25-33. ttp://dx.doi.org/10.1078/0176-1617-00963

Ogura, A., \& Yura, H. (2007). Effects of sandblasting and salt spray on inland plants transplanted to coastal sand dunes. Ecological Research, 23(1), 107-112. http://dx.doi.org/10.1007/s11284-007-0347-2

Rozema, J. P., Bijwaard, F., Dueck, T., \& Wesselman, H. (1982). Salt-spray stimulated growth in strand-line species. Physiologia Plantarum, 56, 204-210. http://dx.doi.org/10.1111/j.1399-3054.1982.tb00326.x

Rozema, J. P., Bijwaard, G., Prast, R., \& Bruekman, M. (1985). Ecophysiological adaptations of coastal halophytes from foredunes and salt marshes. Vegetation, 62, 499-521. http://dx.doi.org/10.1007/BF00044777

Scheiber, S. M., Sandrock, D., Alvarez, E., \& Brennan, M. M. (2008). Effect of salt spray concentration on growth and appearance of 'Gracillimus' maiden grass and 'Hamelin' fountain grass. Hortechnology, 18(1), 34-38.

Touchette, B. W., Rhodes, K. L., Smith, G. A., \& Poole, M. (2009). Salt spray induces osmotic adjustment and tissue rigidity in smooth cordgrass, Spartina alterniflora (Loisel). Estuaries and Coasts, 32(5), 917-925. http://dx.doi.org/10.1007/s12237-009-9178-4

\section{Copyrights}

Copyright for this article is retained by the author(s), with first publication rights granted to the journal.

This is an open-access article distributed under the terms and conditions of the Creative Commons Attribution license (http://creativecommons.org/licenses/by/3.0/). 